\title{
Synthesis of New Schiff Base from Natural Products for Remediation of Water Pollution with Heavy Metals in Industrial Areas
}

\author{
Reham Hassan, ${ }^{1,2}$ Hassan Arida, ${ }^{3,4}$ Manal Montasser, ${ }^{1,5}$ and Nehad Abdel Latif ${ }^{1,6}$ \\ ${ }^{1}$ Chemistry Department, Faculty of Science, Taif University, Saudi Arabia \\ ${ }^{2}$ Chemistry Department, Faculty of Science, Helwan University, Cairo, Egypt \\ ${ }^{3}$ Medicinal Chemistry Department, Pharmacy College, Taif University, Saudi Arabia \\ ${ }^{4}$ Hot Laboratories Center, Atomic Energy Authority, Cairo, Egypt \\ ${ }^{5}$ Central Lab of Pesticides, Agricultural Researches Center, Alexandria, Egypt \\ ${ }^{6}$ Natural Compounds Chemistry Department, Pharmaceutical Industries Division, National Research Center, Cairo, Egypt \\ Correspondence should be addressed to Reham Hassan; hussein6699@yahoo.com
}

Received 5 January 2013; Accepted 20 March 2013

Academic Editor: Huu Hao Ngo

Copyright (C) 2013 Reham Hassan et al. This is an open access article distributed under the Creative Commons Attribution License, which permits unrestricted use, distribution, and reproduction in any medium, provided the original work is properly cited.

A resin of [5-((E)-1-(ethylimino) ethyl)-4, 7-dimethoxy benzofuran-6-ol] Schiff base (EEDB) was prepared, characterized, and successfully applied in the removal of $\mathrm{Cu}$ (II) ions from aqueous real samples. While the metal cation was detected using ICP-OES, the prepared Schiff base resin was characterized by means of FTIR, ${ }^{1} \mathrm{HNMR}$, mass spectral data, and elemental analysis. Various factors affecting the uptake behavior such as $\mathrm{pH}(2-12)$, contact time, effect of initial metal concentration (10-250 ppm), and effect of Schiff base weight (0.1-1.5 gm) were studied. The adsorption process was relatively fast and equilibrium was established after about $60 \mathrm{~min}$. The optimum initial $\mathrm{pH}$ was 8.0 at a metal ion concentration $(100 \mathrm{ppm})$. Under the optimized conditions, the removal of $\mathrm{Cu}$ (II) from real samples of tap water was applied and the removal efficiency reached nearly $85 \%$. The biological activity for Schiff base was also investigated. The results showed that there is no significant difference between the effects of Schiff base on serum (alanine amino transferase) ALT and creatinine concentration activities in treated mice and control, at confidence limits $95 \%$.

\section{Introduction}

Toxic heavy metal contamination of industrial wastewater is an important environmental problem. Many industries such as electroplating, pigments, metallurgical processes, and mining and leather industries release various concentrations of heavy metals. Metal ions such as cadmium, chromium, copper, lead, zinc, manganese, and iron are commonly detected in both natural and industrial effluents [1]. In spite of strict regulations restricting their careless disposal, these metal cations may still emerge in a variety of wastewaters stemming from catalysts, electrical apparatus, painting and coating, extractive metallurgy, antibacterial, insecticides and fungicides, photography, pyrotechnics, smelting, metal electroplating, fertilizer, mining, pigments, stabilizers, alloy industries, electrical wiring, plumbing, heating, roofing and construction piping, water purification, gasoline additives, cable covering, ammunition and battery industries, and sewage sludge [2-4].

In the past few years, special attention has been given to the environmental contamination with heavy metal ions because of their high toxicity and non-biodegradability. The commonly used procedures for removing metal ions from effluents include filtration [5], chemical precipitation [6], chemical coagulation [7], flocculation [8], ion exchange [9], reverse osmosis [10], membrane technologies [11-13], and solvent extraction [14]. However, these methods are limited by high operational cost and/or may also be inefficient in the removal of some toxic metal ions, mainly at trace level concentration $[15,16]$. 
The use of adsorbents of biological and natural origin has emerged in the last decade as one of the most promising alternatives to conventional heavy metal management strategies. One of the promising methods is the use of chelating resins. Chelating resins are easily regenerated from metal ions and they differ from activated carbon and ion exchange resins in their high selectivity in sorption processes [17]. Many articles that cover a vast number of different chelating resins were reported $[18,19]$. Recently, it was reported on the use of magnetic resins in removal of some metals from aqueous solutions [20]. These methods are also cheap and often highly scalable. Attention has recently been focused on natural Schiff bases and its derivatives as bio-adsorbents. A large number of Schiff bases have been studied for their interesting and important properties, for example, their ability to reversibly bind oxygen [21], catalytic activity in hydrogenation of olefins [22] and transfer of an amino group [23], photochromic properties [24], and adsorbing ability towards some toxic metals [25]. The Schiff base complexes were also tested for antibacterial activity against common pathogenic organisms and showed mild to moderate activity [26].

Schiff bases derived from an amino and carbonyl compound are an important class of ligands that coordinate to metal ions via azomethine nitrogen and have been studied extensively [27]. In azomethine derivatives, the $\mathrm{C}=\mathrm{N}$ linkage is essential for biological activity; several azomethines were reported to possess remarkable antibacterial, antifungal, anticancer, and diuretic activities [28]. Schiff bases have wide applications in food industry, dye industry, analytical chemistry, catalysis, fungicidal, agrochemical, and biological activities [29, 30]. With the increasing incidence of deep mycosis there has been increasing emphasis on the screening of new and more effective antimicrobial drugs with low toxicity. Schiff base complexes are considered to be among the most important stereo-chemical models in main group and transition metal coordination chemistry due to their preparative accessibility and structural variety [31]. A considerable number of Schiff base complexes have potential biological interest, being used as more or less successful models of biological compounds [32]. They played a seminal role in the development of modern coordination chemistry and can be found at key points in the development of inorganic biochemistry, catalysis, and optical materials [33].

Khellin (1) is an active principle extracted from the seeds of Ammi visnaga Lam. (Fam. Apiaceae) which is natural source of several furochromones, namely, visnagin, khellin, khellolglucoside, ammiol, and coumarin as visnadin. Khellin and psoralens bind with DNA through cross-links to produce monoadducts. Thus khellin is used in photochemotherapy of dermatoses such as vitiligo and psoriasis [34-38]. It is known that hydrolysis of khellin gives very interesting derivatives namely $\omega$-aceto khellinone and khellinone (2) (Scheme 1). These two products are important molecules for the synthesis of new khellin derivatives [39]. The ring-opening reaction (ROR) of chromone was investigated by ab initio and density functional theory methods by Kona et al. and Ali et al. $[40,41]$.

In the present work, new natural Schiff base was prepared and performed to adsorb $\mathrm{Cu}^{2+}$ ion in aqueous media. The effects of the process parameters such as time of contact, $\mathrm{pH}$, temperature, adsorbent dosage, and initial metal ion concentrations on the removal were investigated. The synthesized ligands were also screened for their biological activity.

\section{Expermental}

2.1. Materials. All reagents used were of Analytical Reagent Grade stated. Sodium hydroxide and nitric acid (69\%) were purchased from Avonchem (UK) and Sigma-Aldrich (Germany), respectively. De-ionized water with conductivity $<0.2 \mu \mathrm{S} / \mathrm{cm}$ obtained from a Milli-Q water system (Millipore, France, Elix 10) was used to prepare standard samples, dilute samples and washing all glassware throughout. Mixed working standard solutions of the investigated mineral and toxic heavy metal ions prepared by appropriate stepwise dilutions of certified stock atomic spectroscopy standards (5\% $\mathrm{HNO}_{3}, 3-500 \mathrm{mg} \mathrm{kg}^{-1}$, Perkin Elmer, USA) were used for ICP-AES validation measurements. Khellin and ethylamine were purchased from Sigma-Aldrich (Germany).

2.2. Apparatus. In the characterization of the prepared Schiff base, the melting points measurements were taken in electro thermal capillary melting points apparatus and are uncorrected. The elemental analyses for $\mathrm{C}, \mathrm{H}$, and $\mathrm{N}$ were done on Vario EL III, Microanalytical Center, Cairo University, Cairo, Egypt. Infrared spectra $\left(\nu, \mathrm{cm}^{-1}\right)$ were recorded on Jasco FT-IR 4100 instruments using $\mathrm{KBr}$ Disks, Microanalytical Center, Cairo University, Cairo, Egypt. ${ }^{1} \mathrm{HNMR}$ spectra were recorded on Varion Mercury VX-300 NMR spectrometer. ${ }^{1} \mathrm{HNMR}$ were run at $300 \mathrm{MHz}$ in deuterated chloroform $\left(\mathrm{CDCl}_{3}\right)$ or dimethyl sulphoxide (DMSO- $\left.\mathrm{d}_{6}\right)$. Chemical shifts are quoted in $\delta$ and were related to that of the solvents. Spectra were internally referenced to TMS. The mass spectra were recorded on Shimadzu GCMS-QP-1000 EX mass spectrometer at 70 e.V. Microanalytical Center, Cairo University, Cairo, Egypt.

The copper ions determination was carried out using a Perkin-Elmer (Optima 2100 DV, Norwalk, CT, USA) inductively coupled plasma atomic emission spectrometer (ICP-AES) instrument connected with an AS 93 Plus autosampler. The $40 \mathrm{MHz}$ free-running generator was operated at a forward power of $1300 \mathrm{~W}$; the outer, intermediate, and Ar carrier gas flow rates were $15.0,0.2$, and $0.8 \mathrm{~L} / \mathrm{min}$, respectively. The pump flow rate was $1.5 \mathrm{~mL} / \mathrm{min}$. The carrier gas flow rate was optimized to obtain maximum signal-tobackground ratios.

HANNA pH-meter was used to measure the $\mathrm{pH}$ after calibration with standard $\mathrm{pH}$ tablets of $\mathrm{pH} 4,7$, and 9 .

All spectrophotometric determinations are carried out using UV-Vis spectrophotometer 160A, Shimadzu, Japan.

2.3. Metal Detection. The copper metal was analyzed using ICP-OES under optimized plasma condition. Using the autosampler, the measured samples were nebulized downstream to the plasma and the concentrations were automatically determined using the standard calibration graph. The system was adjusted to measure the samples in triplicates and 
<smiles>COc1c2occc2c(OC)c2c(=O)cc(C)oc12</smiles>

Khellin

(1) $\downarrow \begin{aligned} & \mathrm{KOH} \\ & \mathrm{C}_{2} \mathrm{H}_{5} \mathrm{OH}\end{aligned}$<smiles>COc1c(C(=O)CC(C)=O)c(O)c(OC)c2occc12</smiles>

$\omega$-aceto khellinone<smiles>COc1c(C(C)=O)c(O)c(OC)c2occc12</smiles>

Khellinone

(2)

Scheme 1: The experimental chemical pathway for khellin hydrolysis.<smiles>COc1c(C(C)=O)c(O)c(OC)c2occc12</smiles>

(2)<smiles>CNCCN</smiles>

SCHEME 2<smiles>CCN=C(C)c1c(O)c(OC)c2occc2c1OC</smiles>

(3) the relative standard deviation was automatically calculated. The RSD was $<2 \%$ and the correlation coefficient was $>0.99998$.

2.4. Preparation of Schiff Base. A Schiff base of 5-((E)-1(substituted imino) ethyl)-4,7-dimethoxy benzofuran-6-ol (3 a-f) was prepared according to Scheme 2, by mixture of compound (2) (0.01 mole) and a suitable amine (ethyl amine 0.01 mole) and then refluxed in absolute ethanol $(30 \mathrm{~mL})$ in presence of a catalytic amount of glacial acetic acid for 12 to 15 hours. The reaction mixture was cooled and the precipitate was filtered and re-crystallized from ethanol to give compounds $(3,4)$.

2.5. The Adsorption Behavior of the Schiff Base toward Copper Ions. In the effect of $\mathrm{pH}$ studies, the uptake experiments were performed at controlled $\mathrm{pH}$ and at room temperature by shaking $0.1 \mathrm{~g}$ of dry Schiff base with $10 \mathrm{~mL}(100 \mathrm{mg} / \mathrm{L})$ metal ion solutions of different $\mathrm{pH}$ values (2-12) for $60 \mathrm{~min}$ at $150 \mathrm{rpm}$. The $\mathrm{pH}$ of the solutions was adjusted using suitable buffers.

The contact time measurements of metal ion uptake using batch method were conducted by placing amounts of $0.1 \mathrm{~g}$ of the prepared Schiff base in a series of stopper conical flasks containing $10 \mathrm{~mL}(100 \mathrm{mg} / \mathrm{L})$ of copper ion solution at $\mathrm{pH}$ 8 . The batch sorption studies were carried out at different contact time intervals $(5 \mathrm{~min}, 15 \mathrm{~min}, 30 \mathrm{~min}, 1 \mathrm{~h}, 2 \mathrm{~h}, 5 \mathrm{~h}$, and $24 \mathrm{~h}$ ). The contents of the flask were shaken using a mechanical shaker with $150 \mathrm{rpm}$ at room temperature. After shaking the samples were individually filtrated and analyzed of residual metal ion concentration in solution.

The effect of initial concentration of the metal ion on the uptake of copper ions by Schiff base was carried out by placing 
$0.1 \mathrm{~g}$ of dry Schiff base in a series of flasks containing $10 \mathrm{~mL}$ of copper ions at definite concentrations (10-250 mg/L) and at $\mathrm{pH}$. The contents of the flasks were equilibrated on the shaker with $150 \mathrm{rpm}$ at room temperature for $60 \mathrm{~min}$. After adsorption, the samples were filtered and the concentration of the metal ion was determined.

In the effect of the Schiff base weight studies, measurements of metal ion uptake using batch method were performed by placing different weights of adsorbent $(0.1 \mathrm{~g}$, $0.25 \mathrm{~g}, 0.5 \mathrm{~g}, 0.8 \mathrm{~g}, 1 \mathrm{~g}, 1.5 \mathrm{~g}$ ) in a series of stopper conical flask containing $10 \mathrm{~mL}(10 \mathrm{mg} / \mathrm{L}, \mathrm{pH} 8)$ of copper ions solutions. The contents of the flasks were shaking on a shaker with $150 \mathrm{rpm}$ for $60 \mathrm{~min}$ at room temperature.

In all batch sorption studies, the percentage of metal ion removal was evaluated from the following equation [1]:

$$
\% \text { Removal }=\frac{\left(C_{0}-C_{e}\right)}{C_{0}} \times 100,
$$

where $C_{0}$ is the initial metal ion concentration and $C_{e}$ is the metal ion concentration at equilibrium.

2.6. Real Samples Applications. Aliquots of tap water collected from Taif City were used as real samples in this study. Under the optimized conditions of the adsorption behavior of the prepared Schiff base towards copper ions mentioned above, the copper content of the tested real samples were treated with Schiff base similarly to the previous reported procedures. The copper concentration of the samples was measured before and after treatment. The removal percent was then calculated similarly.

2.7. Measurement of Biological Activity for Schiff Base. A number of 10 mice were purchased and used in the biological activity studies to examine the effect of treated water using the investigated Schiff base. The mice were kept at the animal house center belong to Taif University for one week and water fed ad libitum. The mice were divided into two groups with five in each. The first group received distilled water and was considered as a control group while the second group received the filtered water after treatment with the prepared Schiff base. The experiment extended for 10 days after which the mice were killed using diethyl ether and the blood samples were individually obtained from medal canthus of the eye. The blood samples were allowed to clot and the clear sera were kept in refrigerator without freezing till analysis.

In this study, the activity of alanine amino transferase (ALT) was determined using ALT kit obtained from HUMAN Company. Kinetic method described by Schumann and Kluake [42] and used for the determination of ALT activity using $200 \mu \mathrm{L}$ of serum and $1000 \mu \mathrm{L}$ consisting of buffer, working solution, and enzyme substrate. The mixture was measured kinetically using UV-Vis spectrophotometer (160A Shimadzu) at $340 \mathrm{~nm}$ for 5 minutes interval. The ALT activity was measured according to the following equation:

$$
\operatorname{ALT} \text { activity }(\mathrm{U} / \mathrm{L})=\Delta \text { absorbance } \times 1151 \text {. }
$$

Serum creatinine concentration was also measured using creatinine kit obtained from HUMAN Company. Kinetic

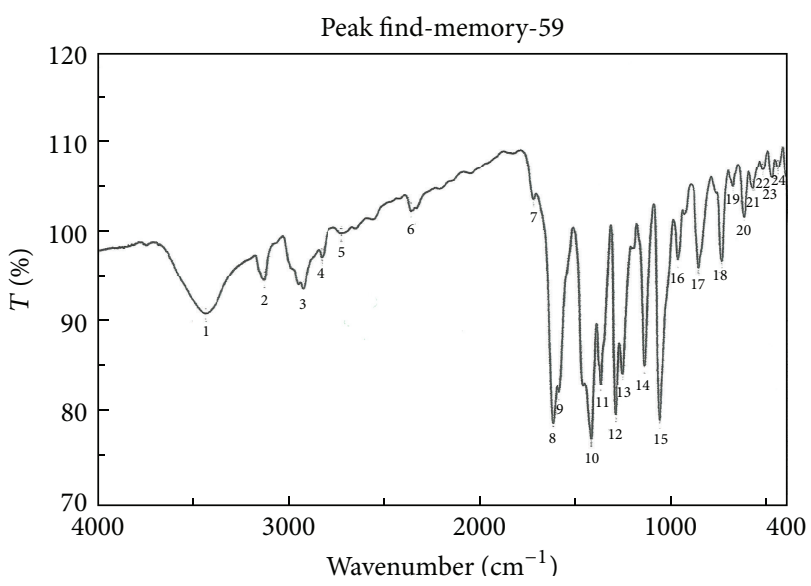

FIGURE 1: The FTIR spectra of EEDB resin.

method described by to the Schirmeister [43] was used in which $100 \mu \mathrm{L}$ of serum and $1000 \mu \mathrm{L}$ of working solution consisting of buffer, picric acid solution, and sodium hydroxide was applied. The mixture was measured kinetically using UV-Vis spectrophotometer (160A Shimadzu) at $500 \mathrm{~nm}$ for 2 minutes interval. The serum creatinine was measured according to the following equation:

$$
\begin{aligned}
& \text { creatinine concentration }(\mathrm{mg} / \mathrm{dL}) \\
& \qquad=\left(\frac{\Delta \text { absorbance for sample }}{\Delta \text { absorbance for standard }}\right) \times 2.0 .
\end{aligned}
$$

\section{Results and Discussion}

3.1. Characterization of the Schiff Base. The starting material (2) was prepared as indicated in Scheme 1. Its IR spectrum showed absorption bands at $3300 \mathrm{~cm}^{-1}(\mathrm{OH}), 3100 \mathrm{~cm}^{-1}$ (aromatic $\mathrm{C}-\mathrm{H}), 1711 \mathrm{~cm}^{-1}$ ( $-\mathrm{C}=\mathrm{O}$ carbonyl stretching). The ${ }^{1} \mathrm{HNMR}$ spectrum exhibited a singlet due to $(-\mathrm{OH})$ group at 9.3 ppm which disappeared using $\mathrm{D}_{2} \mathrm{O}$. Methyl at acetyl group resonated as singlet signal at $2 \mathrm{ppm}$.

Schiff base (3) was prepared as indicated in Scheme 2 similarly to those previously described [44], by refluxing solutions of khellinone and amines in absolute ethanol for 1215 hours, in the presence of catalytic amount of glacial acetic acid. The structure of the products was inferred from their analytical and spectral data. The IR spectra of compounds (3) showed characteristics at 3400-3200 for OH, showed not only the absence of $-\mathrm{C}=\mathrm{O}$ but also the presence of $\mathrm{C}=\mathrm{N}$ at $1660 \mathrm{~cm}^{-1}$. The ${ }^{1} \mathrm{HNMR}$ spectra showed the presence of the entered moiety.

The main bands observed in the IR spectrum of [5-((E)1-(ethylimino) ethyl)-4, 7-dimethoxy benzofuran-6-ol] (3) (EEDB) was presented in Figure 1. As can be seen, a strong absorption band at $1622 \mathrm{~cm}^{-1}$ is attributed to $\mathrm{C}=\mathrm{N}$ vibrations characteristic of imines $[45,46]$. The bands at 3437,3135 , and $2930 \mathrm{~cm}^{-1}$ are attributed to the $-\mathrm{OH}, \mathrm{C}-\mathrm{H}$ aromatic, and C$\mathrm{H}$ aliphatic, respectively. 


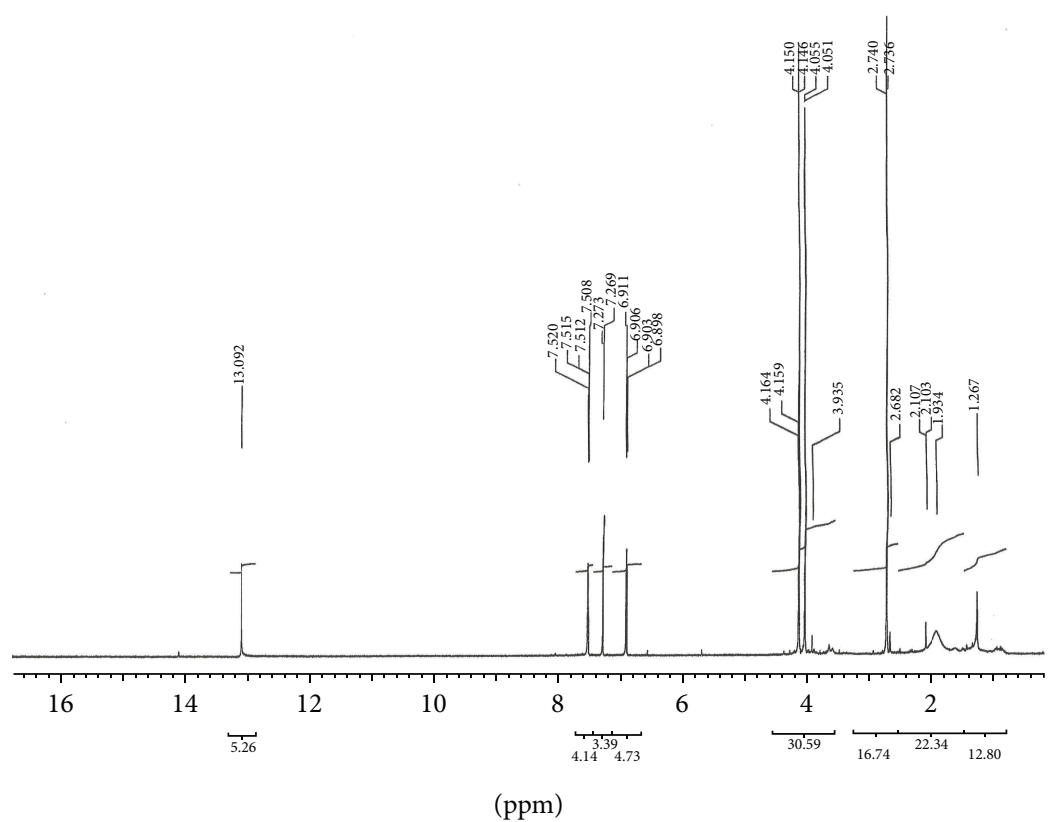

(a)

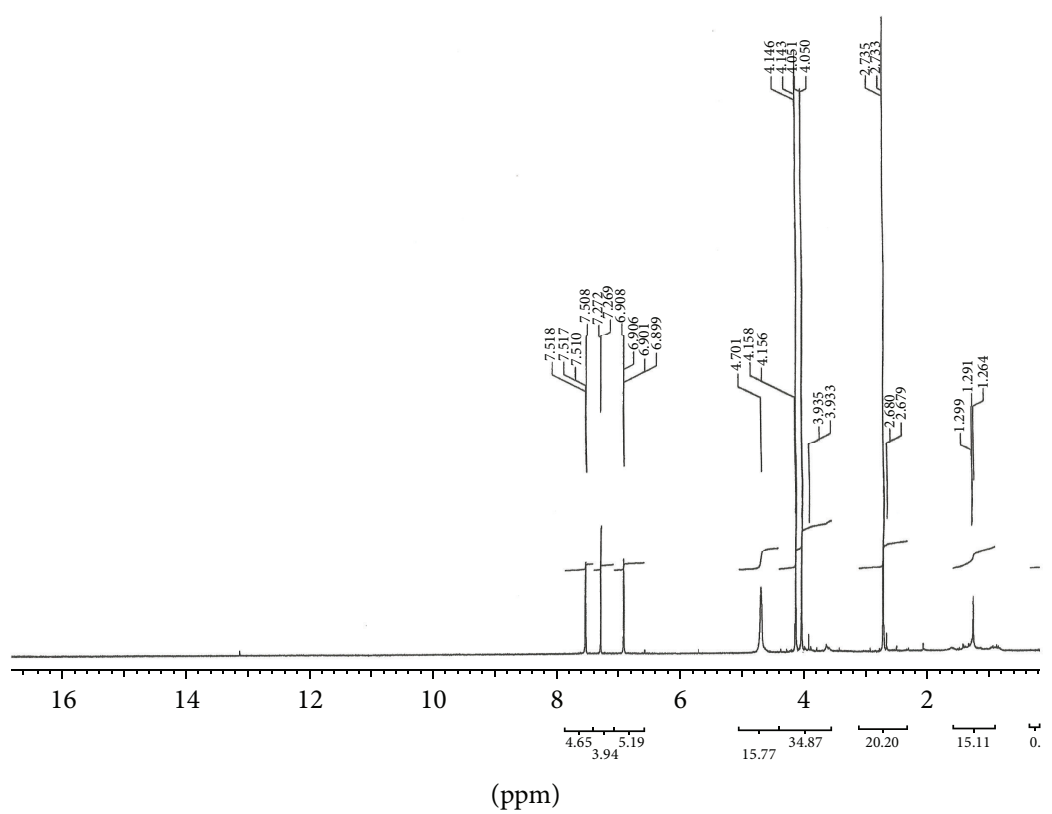

(b)

Figure 2: (a) ${ }^{1} \mathrm{H}-\mathrm{NMR}$ spectra of EEDB resin in $\mathrm{CDCL}_{3}-\mathrm{H}$. (b) ${ }^{1} \mathrm{H}-\mathrm{NMR}$ spectra of EEDB resin in DMSO-D ${ }_{2} \mathrm{O}$.

The ${ }^{1} \mathrm{H}$-NMR spectra of (3) (EEDB) in $\mathrm{CDCL}_{3}$ and in DMSO $/ \mathrm{D}_{2} \mathrm{O}$ were shown in Figures $2(\mathrm{a})$ and $2(\mathrm{~b})$, respectively. The spectrum confirms the presence of the triplet signal at $2.1 \mathrm{ppm}$ and the quartet signal at $2.7 \mathrm{ppm}$ which are characteristic for ethyl group and a single signal at $13.09 \mathrm{ppm}$ for $\mathrm{OH}$ group exchangeable with $\mathrm{D}_{2} \mathrm{O}$.

Mass spectrum of (3) $\mathrm{m} / \mathrm{z}(\%)$ was shown in Figure 3. From the figure, it was observed that the molecular ion peak at 263 is attributed with the molecular weight and a base peak at $236(100)$.
TABLE 1: Elemental analysis for (EEDB resin).

\begin{tabular}{lccc}
\hline$\%$ & $\mathrm{C}$ & $\mathrm{H}$ & $\mathrm{N}$ \\
\hline Calculated & 71.19 & 7.20 & 5.93 \\
Found & 71.15 & 7.19 & 5.90 \\
\hline
\end{tabular}

The elemental analysis for (EEDB) resin can be shown in Table 1. 


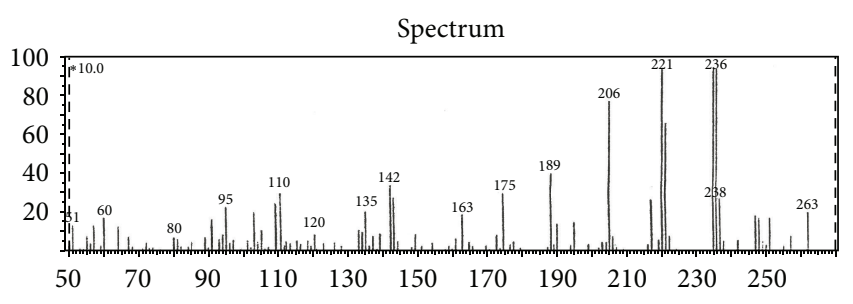

FIgURE 3: Mass spectrum of EEDB resin.

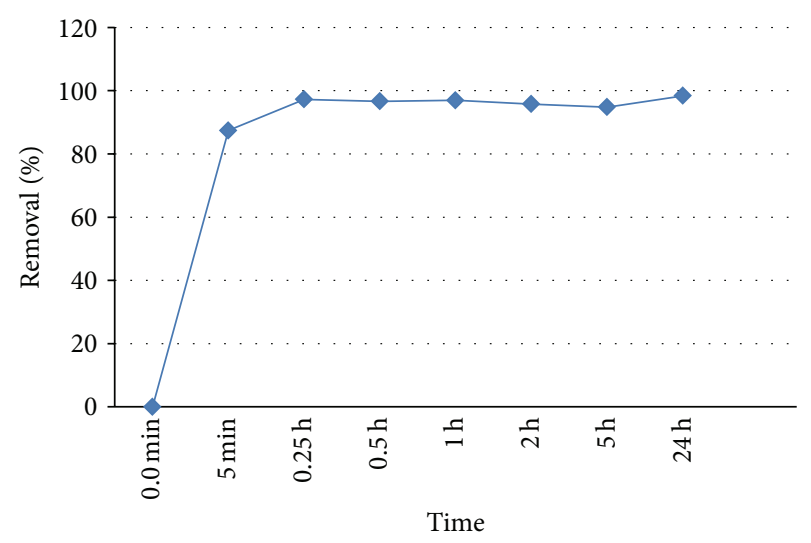

FIGURE 4: Effect of the contact time on the removal of Copper (II) ion using Schiff base.

3.2. The Adsorption Behavior Studies of Schiff Base towards Copper Ions. The effect of contact time on the rate of metal ion uptake onto (EEDB) was presented in Figure 4. As can be seen, at the beginning of adsorption, the values of \% removal increased steadily, and then after 1 hour, the change turned slow. Thus, the adsorption of the metal ion on (EEDB) was speedy. After about $60 \mathrm{~min}$, the adsorption quantity of the metal ion showed nearly no change. This behavior gives away a slow approach to equilibrium. The nature of adsorbent and its available sorption sites affected the time needed to reach the equilibrium [47].

The effect of $\mathrm{pH}$ of the metal ion test solution is an important parameter for adsorption of metal ions because it affects the solubility of the metal ions, concentration of the counter ions, on the functional groups of the adsorbent and the degree of ionization of the adsorbent [1]. To examine the effect of $\mathrm{pH}$ on metal ion removal efficiency, the $\mathrm{pH}$ was varied from 2.0 to 12.0 for $\mathrm{Cu}$ (II) and the $\mathrm{pH}$ of the solutions was adjusted to different values using suitable buffers. As shown in Figure 5, the uptake of free ionic $\mathrm{Cu}$ (II) depends greatly on $\mathrm{pH}$, where there is optimal metal removal efficiency. The concentrations of Copper (II) in the different solutions were properly determined directly before and after shaking the mixture for $60 \mathrm{~min}$. The removal efficiency was calculated and the results obtained were represented in Figure 5. The data showed that the removal percentage of $\mathrm{Cu}$ (II) was dependent on the $\mathrm{pH}$ of the test solution in the investigated $\mathrm{pH}$ ranges (212) which indicates that the maximum adsorption affinities take place at $\mathrm{pH} 8.0$ (Figure 8). This behavior is expected, as the acidity of the medium can affect the metal uptake on

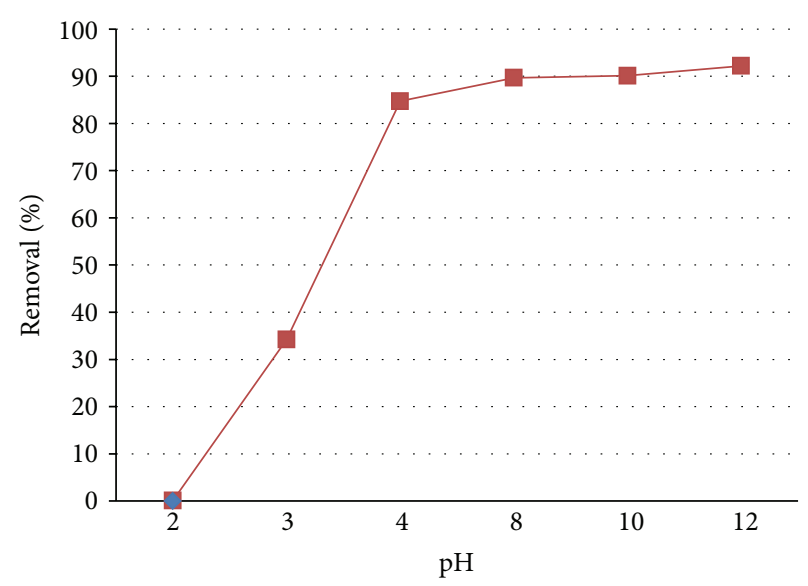

Figure 5: Effect of the $\mathrm{pH}$ on the removal of Copper (II) ion using Schiff base.

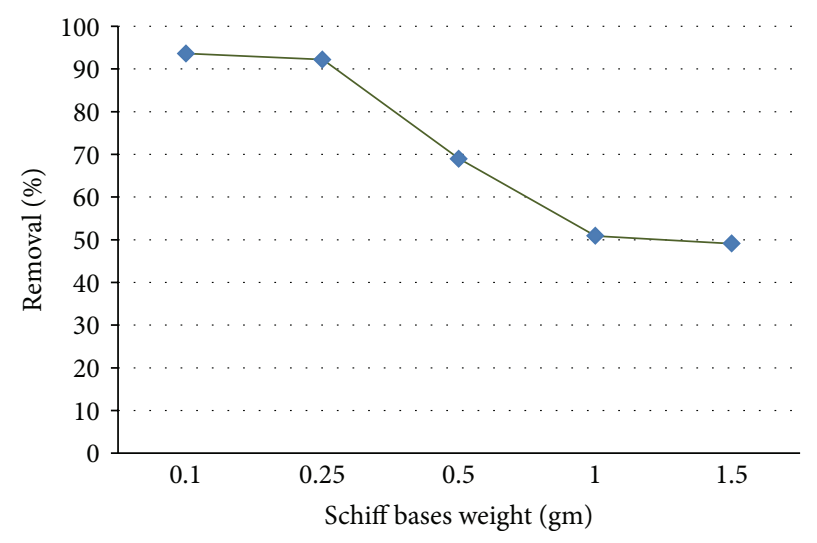

FIgURE 6: Effect of Schiff bases weight on metal ion removal.

the natural sorbent because hydrogen ions could compete with metallic ions for active sites on the natural sorbent surface. Also at low $\mathrm{pH}$, most of the active functional groups in the resin were ionized and presented in the protonated positively charged form electrostatic repulsion between the metal cations and the protonated groups may prevent the adsorption of the metal ions onto the resin [48]. At $\mathrm{pH}>8$ the metal ion retention becomes nearly stable because small amount of metal cations started to deposit as hydroxides. This also supports the chelation of the cations on the resin. Considering the formation of metal hydroxides when the $\mathrm{pH}$ value of the solution increases, the $\mathrm{pH} 8$ was selected as the optimum $\mathrm{pH}$ for this chelation.

On the other hand, the influence of Schiff base weight on heavy metal ions sorption was investigated. Different weight values (0.1-1.5 gm) were used by adding definite weights of solid resin to a definite concentration of the $\mathrm{Cu}^{2+}$ metal ion $(100 \mathrm{mg} / \mathrm{L})$. The results obtained were shown in Figure 6. As can be seen, the optimum Schiff base weight was $0.1 \mathrm{gm}$ which showed maximum metal ion removal percentage (92.2\%). It can be seen also that the increasing of the resin weight results in a decrease in the amount of the metal ion adsorbed as a result of the competition between the metal ions and 


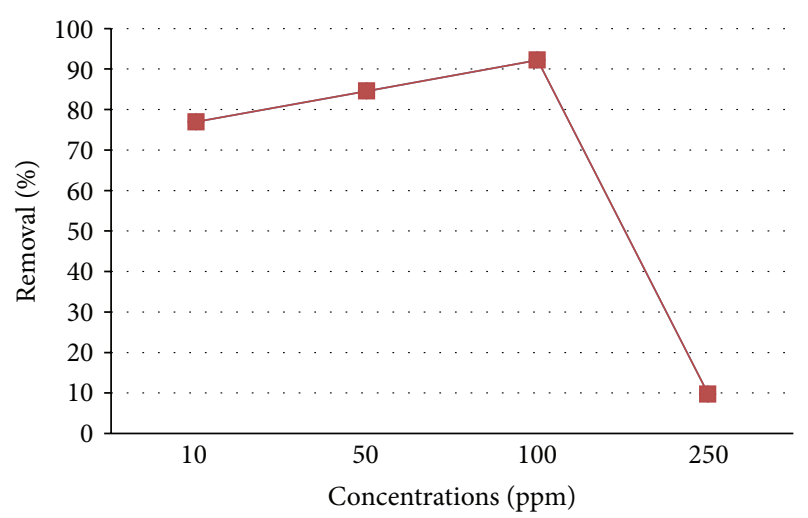

FIGURE 7: Effect of initial metal ion concentrations on metal ion removal using Schiff base.

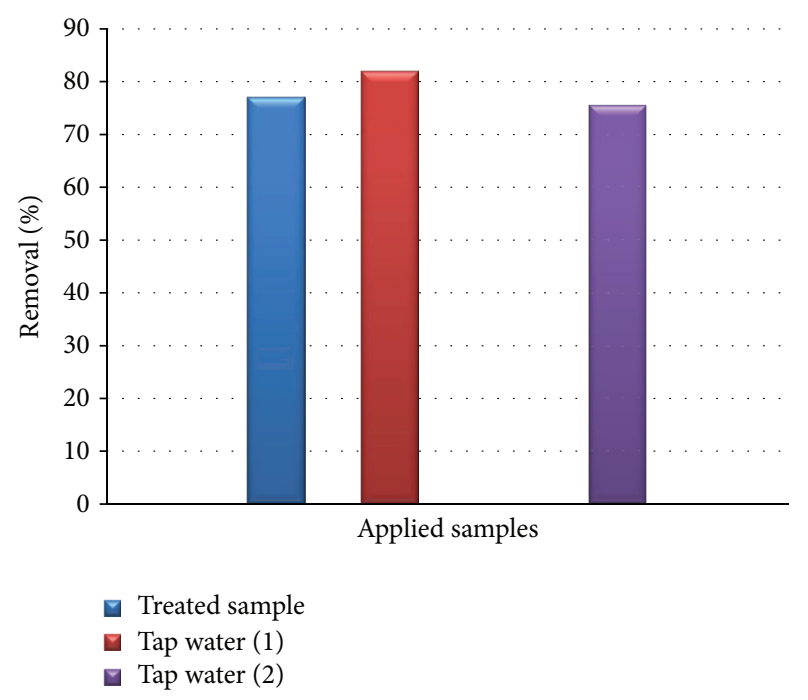

Figure 8: Removal percentage of $\mathrm{Cu}$ (II) from Tap water samples.

the bio-sorption [49]. The reduction in uptake is probably due to the excess of sorbent quantity inhibiting the approach of adsorbed ions to the active sites of the sorbent. Generally, with increasing resin weight, there is a little decrease in metal ion removal which can be attributed to the presence of sorption sites of different affinities [50].

The effect of initial metal ion concentration on the adsorption behavior of the prepared Schiff base towards copper ion was investigated and the results obtained were presented in Figure 7. The metal uptake mechanism is particularly dependent on the initial heavy metal concentration; at low concentrations, metal ions are adsorbed by specific active sites, while with increasing metal concentrations the binding sites become more quickly saturated as the amount of biomass concentration remained constant [51]. As shown in Figure 7, the amount of metal ion removal percentage at optimum $\mathrm{pH}$ values and after 60 min contact time was decreased with increasing the initial metal ion concentration for metal ion studied. Similar observations were reported for adsorption ions on cross-linked Schiff base [48]. On the other hand, the
TABLE 2: Comparison of removal efficiency \% of $\mathrm{Cu}$ (II) with different methods.

\begin{tabular}{lc}
\hline Resin & Removal efficiency \% of Cu (II) \\
\hline (EEDB) $^{*}$ & $82 \%$ \\
(NCS) & $20 \%$ \\
(CSTG) & $58 \%$ \\
(TMCS) & $88 \%$ \\
(CSIS) & $90 \%$ \\
\hline
\end{tabular}

${ }^{*}$ Schiff base resin in our study.

uptake of metal ions obviously increases with increasing the initial concentration till reaching the plateau [51].

3.3. Real Samples Application. Under the optimized conditions, namely, $\mathrm{pH} \mathrm{8}$, contact time $60 \mathrm{~min}$, and (EEDB) Schiff base weight of $(0.1 \mathrm{~g})$, the study was applied to two real samples of tap water in comparison with one synthetic sample. The results showed that there was about $\sim 75-82 \%$ removal of $\mathrm{Cu}$ (II) from the investigated real water samples. This study simulates the elimination of heavy metals from drinking water by using natural substances as (EEDB) Schiff base resin which is very safe and has no effect on the liver or kidney functions for human. These findings improve the applicability of the prepared Schiff base in the copper metal removal and also can be applied to other heavy metals removal from aqueous media in environmental and industrials strategies. Only there may be some differences in the affected parameters like $\mathrm{pH}$, contact time, and actually in the removal percentage, and this was already done by the previous similar studies reported in the literature.

Now, it would be interesting to have compared the removal efficiency of the system proposed with other procedure that is usually used or with other similar systems reported in the literature as shown in Table 2.

3.4. Schiff Base Biological Activity. Copper is essential for good human health but a very high intake can cause adverse health problems, such as liver and kidney damage [52]. The recommended daily intakes of copper is $1.5 \mathrm{mg} \mathrm{kg}^{-1}$ for adult males and $3.0 \mathrm{mg} \mathrm{kg}^{-1}$ for adult females [53]. However, the maximum permitted levels of copper in foodstuffs and drinking water are $3.0 \mathrm{mg} \mathrm{kg}^{-1}$ [54].

In this study, the data were analyzed statistically by analysis of SPSS and Minitab programs. Statistical analysis which illustrated in Figures 9(a), 9(b), 10(a) and 10(b) indicated that there is no significant difference between the effects of Schiff base on serum ALT and creatinine concentration activities in treated mice and control, at confidence limits 95\%. These reflect the safety uses of the suggested Schiff base in the heavy metals removal from the tap water and environmental samples. Also, these data reflect that the content of the remaining $\mathrm{Cu}^{2+}$ in the solution after the removing procedure 


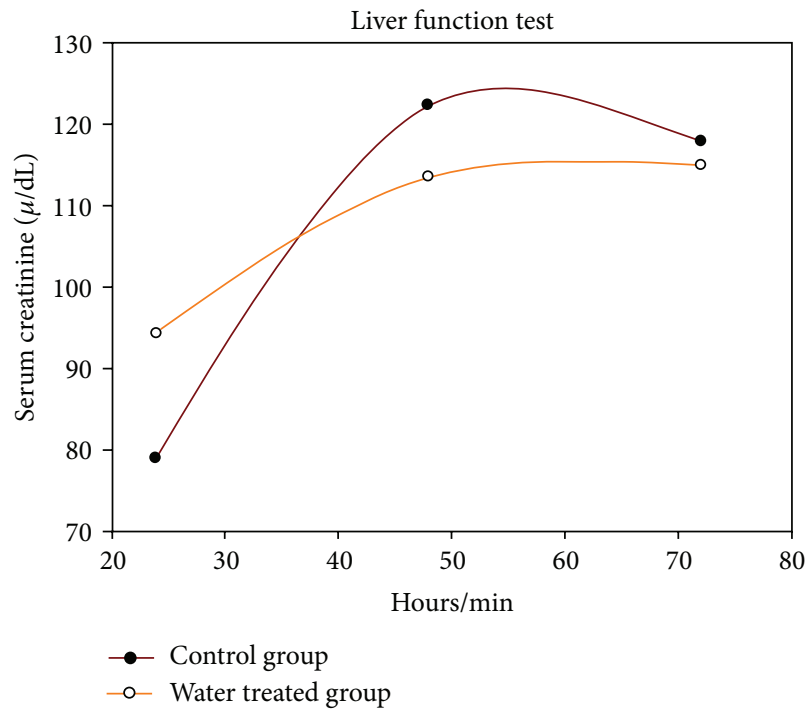

(a)

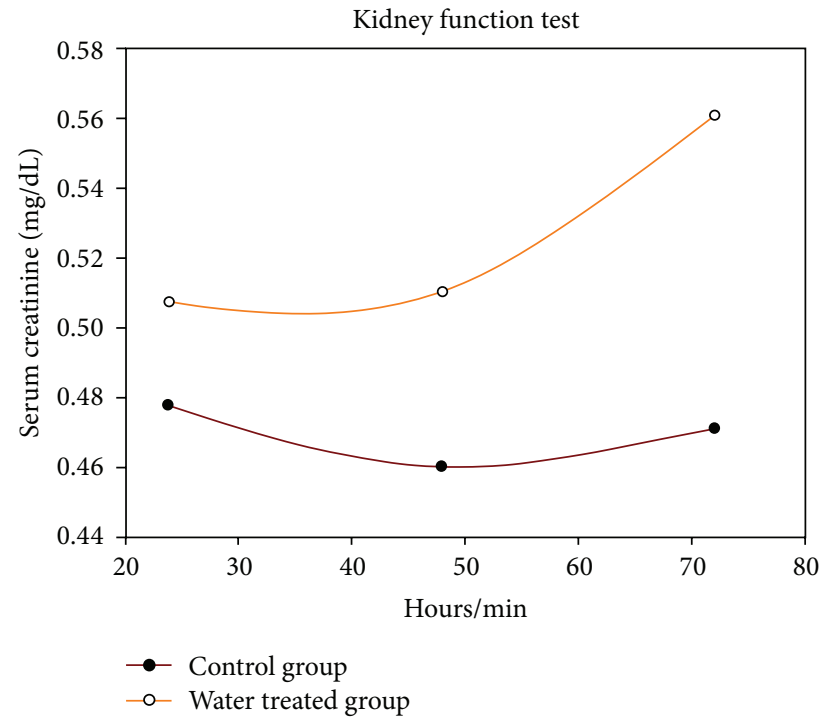

(b)

FIGURE 9: Effects of Schiff base on Liver (a) and Kidney (b) functions.

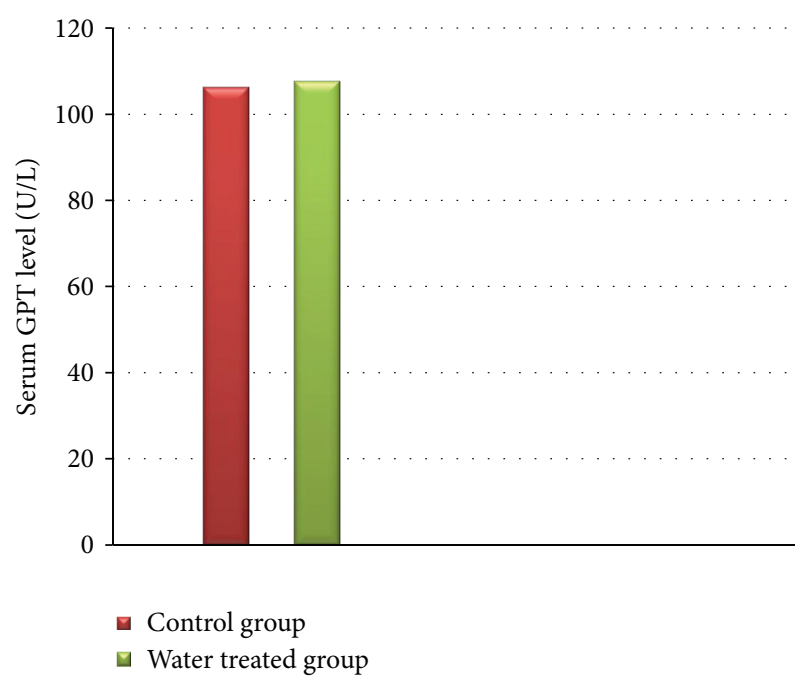

(a)

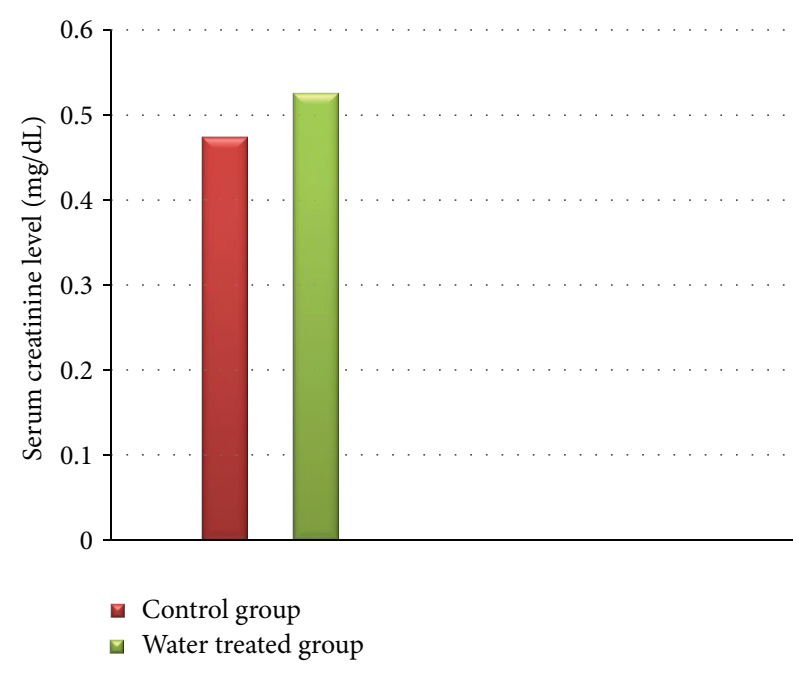

(b)

FIGURE 10: (a) Effect of Schiff base on serum ALT activity. (b) Effect of Schiff base on serum creatinine concentration activity.

must be of course below the toxic level because there is no effect on the liver or kidney functions for human.

\section{Conclusion}

In conclusion, a resin of a new natural Schiff base (EEDB) was prepared, characterized (by means of FTIR, ${ }^{1} \mathrm{HNMR}$, mass spectral data, and elemental analysis), and successfully applied in the removal of $\mathrm{Cu}$ (II) ions from aqueous real samples using ICP-OES. The results include studying the various factors affecting the uptake behavior in order to select the optimum condition for the removal of $\mathrm{Cu}$ (II) from real samples of tap water and we find that the removal efficiency reached nearly $82 \%$. The biological activity for Schiff base was also investigated. The results showed that there is no significant difference between the effects of Schiff base on serum ALT (alanine amino transferase) and creatinine concentration activities in treated mice and control, at confidence limits $95 \%$.

\section{Acknowledgment}

The authors gratefully acknowledge Taif University, Saudi Arabia, for financial support of this project under Contract no. 1923-433-1.

\section{References}

[1] G. O. El-Sayed, H. A. Dessouki, and S. S. Ibrahiem, "Removal of $\mathrm{Zn}$ (ii), Cd(ii) and $\mathrm{Mn}$ (ii) from aqueous solutions by adsorption 
on maize stalks," Malaysian Journal of Analytical Sciences, vol. 15, no. 1, pp. 8-21, 2011.

[2] S. Kocaoba and T. Akyuz, "Effects of conditioning of sepiolite prior to cobalt and nickel removal," Desalination, vol. 181, no. 1-3, pp. 313-318, 2005.

[3] F. C. Wu, R. L. Tseng, and R. S. Juang, "Kinetic modeling of liquid-phase adsorption of reactive dyes and metal ions on chitosan," Water Research, vol. 35, no. 3, pp. 613-618, 2001.

[4] L. Zhou, Y. Wang, Z. Liu, and Q. Huang, "Characteristics of equilibrium, kinetics studies for adsorption of $\mathrm{Hg}(\mathrm{II}), \mathrm{Cu}$ (II), and $\mathrm{Ni}(\mathrm{II})$ ions by thiourea-modified magnetic chitosan microspheres," Journal of Hazardous Materials, vol. 161, no. 2-3, pp. 995-1002, 2009.

[5] H. Bessbousse, T. Rhlalou, J. F. Verchère, and L. Lebrun, "Removal of heavy metal ions from aqueous solutions by filtration with a novel complexing membrane containing poly(ethyleneimine) in a poly(vinyl alcohol) matrix," Journal of Membrane Science, vol. 307, no. 2, pp. 249-259, 2008.

[6] J. O. Esalah, M. E. Weber, and J. H. Vera, "Removal of lead from aqueous solutions by precipitation with sodium di- $(n-$ octyl) phosphinate," Separation and Purification Technology, vol. 18, no. 1, pp. 25-36, 1999.

[7] A. G. El Samrani, B. S. Lartiges, and F. Villiéras, "Chemical coagulation of combined sewer overflow: heavy metal removal and treatment optimization," Water Research, vol. 42, no. 4-5, pp. 951-960, 2008.

[8] E. Ofir, Y. Oren, and A. Adin, "Comparing pretreatment by iron of electro-flocculation and chemical flocculation," Desalination, vol. 204, no. 1-3, pp. 87-93, 2007.

[9] L. C. Lin, J. K. Li, and R. S. Juang, "Removal of $\mathrm{Cu}$ (II) and $\mathrm{Ni}(\mathrm{II})$ from aqueous solutions using batch and fixed-bed ion exchange processes," Desalination, vol. 225, no. 1-3, pp. 249-259, 2008.

[10] Y. Benito and M. L. Ruíz, "Reverse osmosis applied to metal finishing wastewater," Desalination, vol. 142, no. 3, pp. 229-234, 2002.

[11] C. A. Cooper, Y. S. Lin, and M. Gonzalez, "Separation properties of surface modified silica supported liquid membranes for divalent metal removal/recovery," Journal of Membrane Science, vol. 229, no. 1-2, pp. 11-25, 2004.

[12] R. S. Juang and R. C. Shiau, "Metal removal from aqueous solutions using chitosan-enhanced membrane filtration," Journal of Membrane Science, vol. 165, no. 2, pp. 159-167, 2000.

[13] M. M. Nasef and A. H. Yahaya, "Adsorption of some heavy metal ions from aqueous solutions on Nafion 117 membrane," Desalination, vol. 249, no. 2, pp. 677-681, 2009.

[14] S. K. Gupta, N. S. Rathore, J. V. Sonawane et al., "Dispersion-free solvent extraction of $\mathrm{U}(\mathrm{VI})$ in macro amount from nitric acid solutions using hollow fiber contactor," Journal of Membrane Science, vol. 300, no. 1-2, pp. 131-136, 2007.

[15] M. Yurdakoç, Y. Seki, S. Karahan, and K. Yurdakoç, "Kinetic and thermodynamic studies of boron removal by Siral 5, Siral 40, and Siral 80," Journal of Colloid and Interface Science, vol. 286, no. 2, pp. 440-446, 2005.

[16] M. Monier, D. M. Ayad, and A. A. Sarhan, "Adsorption of Cu(II), $\mathrm{Hg}(\mathrm{II})$, and $\mathrm{Ni}(\mathrm{II})$ ions by modified natural wool chelating fibers," Journal of Hazardous Materials, vol. 176, no. 1-3, pp. 348355, 2010.

[17] A. M. Donia, A. A. Atia, and K. Z. Elwakeel, "Selective separation of mercury(II) using magnetic chitosan resin modified with Schiff's base derived from thiourea and glutaraldehyde," Journal of Hazardous Materials, vol. 151, no. 2-3, pp. 372-379, 2008.
[18] L. Wan, Y. Wang, and S. Qian, "Study on the adsorption properties of novel crown ether crosslinked chitosan for metal ions," Journal of Applied Polymer Science, vol. 84, no. 1, pp. 2934, 2002.

[19] A. J. Varma, S. V. Deshpande, and J. F. Kennedy, "Metal complexation by chitosan and its derivatives: a review," Carbohydrate Polymers, vol. 55, no. 1, pp. 77-93, 2004.

[20] A. A. Atia, A. M. Donia, and K. Z. Elwakeel, "Selective separation of mercury (II) using a synthetic resin containing amine and mercaptan as chelating groups," Reactive and Functional Polymers, vol. 65, no. 3, pp. 267-275, 2005.

[21] D. Sanz, A. Perona, R. M. Claramunt, and J. Elguero, "Synthesis and spectroscopic properties of Schiff bases derived from 3hydroxy-4-pyridinecarboxaldehyde," Tetrahedron, vol. 61, no. 1, pp. 145-154, 2005.

[22] G. H. Olie and S. Olive, The Chemistry of the Catalyzes Hydrogenation of Carbon Monoxide, Springer, Berlin, Germany, 1984.

[23] M. Curini, F. Epifano, F. Maltese, and M. C. Marcotullio, "Novel chiral Schiff base ligands from amino acid amides and salicylaldehyde," Tetrahedron Letters, vol. 43, no. 21, pp. 38213823, 2002.

[24] N. E. Taha, Synthesis, characterization, photophysical and computational study of Schiff base ligands and their Zn (II) complexes [Ph.D. thesis], University Sains Malaysia, Kuala Lumpur, Malaysia, 2009, Thesis submitted in fulfillment of the requirements for the degree of Doctor of Philosophy.

[25] M. Monier, "Adsorption of $\mathrm{Hg}^{2+}, \mathrm{Cu}^{2+}$ and $\mathrm{Zn}^{2+}$ ions from aqueous solution using formaldehyde cross-linked modified chitosan-thioglyceraldehyde Schiff's base," International Journal of Biological Macromolecules, vol. 50, pp. 773-781, 2012.

[26] G. G. Mohamed, M. M. Omar, and A. M. Hindy, "Metal complexes of Schiff bases: preparation, characterization, and biological activity," Turkish Journal of Chemistry, vol. 30, no. 3, pp. 361-382, 2006.

[27] N. Raman, Y. P. Raja, and A. Kulandaisamy, "Synthesis and characterisation of $\mathrm{Cu}(\mathrm{II}), \mathrm{Ni}(\mathrm{II}), \mathrm{Mn}(\mathrm{II}), \mathrm{Zn}(\mathrm{II})$ and $\mathrm{VO}(\mathrm{II})$ Schiff base complexes derived fromo-phenylenediamine and acetoacetanilide," Journal of Chemical Sciences, vol. 113, no. 3, pp. 183-189, 2001.

[28] C. T. Barboiu, M. Luca, C. Pop, E. Brewster, and M. E. Dinculescu, "Carbonic anhydrase activators, part 14: syntheses of mono and bis pyridinium salt derivatives of 2-amino5-(2-aminoethyl)- and 2-amino-5-(3-aminopropyl)-1,3,4thiadiazole and their interaction with isozyme II," European Journal of Medicinal Chemistry, vol. 31, no. 7-8, pp. 597-606, 1996.

[29] S. Gaur, "Physico-chemical and biological properties of Mn(II), $\mathrm{Co}(\mathrm{II}), \mathrm{Ni}(\mathrm{II})$ and $\mathrm{Cu}(\mathrm{II})$ chelates of Schiff bases," Asian Journal of Chemistry, vol. 15, no. 1, pp. 250-254, 2003.

[30] M. J. Gemi, C. Biles, B. J. Keiser et al., "Novel 1,5diphenylpyrazole nonnucleoside HIV-1 reverse transcriptase inhibitors with enhanced activity versus the delavirdineresistant P236L mutant: lead identification and SAR of 3- and 4-substituted derivatives," Journal of Medicinal Chemistry, vol. 43, no. 5, pp. 1034-1040, 2000.

[31] H. Keypour, M. Rezaeivala, L. Valencia, P. Pérez-Lourido, and H. R. Khavasi, "Synthesis and characterization of some new $\mathrm{Co}$ (II) and Cd(II) macroacyclic Schiff-base complexes containing piperazine moiety," Polyhedron, vol. 28, no. 17, pp. 3755-3758, 2009. 
[32] K. S. Suslick and T. J. Reinert, "The synthetic analogs of $\mathrm{O}_{2}{ }^{-}$ binding heme proteins," Journal of Chemical Education, vol. 62 , no. 11, p. 974, 1988.

[33] F. Tisato, F. Refosco, and G. Bandoli, "Structural survey of technetium complexes," Coordination Chemistry Reviews, vol. 135-136, pp. 325-397, 1994.

[34] G. Orecchia and L. Perfetti, "Photochemotherapy with topical khellin and sunlight in vitiligo," Dermatology, vol. 184, no. 2, pp. 120-123, 1992.

[35] A. Abdel-Fattah, M. N. Aboul-Enein, G. M. Wassel, and B. S. ElMenshawi, "An approach to the treatment of vitiligo by khellin," Dermatologica, vol. 165, no. 2, pp. 136-140, 1982.

[36] S. Valkova, M. Trashlieva, and P. Christova, "Treatment of vitiligo with local khellin and UVA: comparison with systemic PUVA," Clinical and Experimental Dermatology, vol. 29, no. 2, pp. 180-184, 2004.

[37] G. Carlie, N. B. A. Ntusi, P. A. Hulley, and S. H. Kidson, "KUVA (khellin plus ultraviolet A) stimulates proliferation and melanogenesis in normal human melanocytes and melanoma cells in vitro," British Journal of Dermatology, vol. 149, no. 4, pp. 707-717, 2003.

[38] P. Morliere, H. Honigsmann, D. Averbeck et al., "Phototherapeutic, photobiologic, and photosensitizing properties of khellin," Journal of Investigative Dermatology, vol. 90, no. 5, pp. 720-724, 1988.

[39] A. Chergui, Contribution à l'étude de la furochromone "khelline" extraction-reactivitéhémisynthèse [Thèse de Magister], Université des sciences et de la technologie Houari Boumediene, Algiers, Algeria, 1986.

[40] J. Kona, W. M. F. Fabian, and P. Zahradnik, "Ab initio and DFT study on the mechanism of ring-opening reactions of $4 \mathrm{H}-1-$ benzopyran-4-one with hydroxide ion," Journal of the Chemical Society, Perkin Transactions, vol. 2, pp. 422-426, 2001.

[41] F. Ali, S. El-Aoufi, A. Chergui, H. Y. Aboul-Enein, and B. Maouche, "Theoretical study of hydrolysis mechanism of khellin," Journal of the Iranian Chemical Society, vol. 5, no. 3, pp. 506-513, 2007.

[42] G. Schumann and R. Kluake, "New IFCC reference procedures for the determination of catalytic activity concentrations of five enzymes in serum: preliminary upper reference limits obtained in hospitalized subjects," Clinical Chemistry Acta, vol. 327, no. 1-2, pp. 69-79, 2003.

[43] J. Schirmeister, "Plasmakreatinin als grober Indikator der Nierenfunktion," Deutsch Medizinisches Wörterbuch, vol. 89, no. 21, pp. 1018-1023, 1964.

[44] M. Cacic, M. Monlar, B. Sarkanj, E. Has-Schon, and V. Rajkovic, "Synthesis and antioxidant activity of some new coumarinyl1,3-thiazolidine-4-one," Molecules, vol. 15, no. 10, pp. 6795-6809, 2010.

[45] A. Singh, S. S. Narvi, P. K. Dutta, and N. D. Pandey, "External stimuli response on a novel chitosan hydrogel crosslinked with formaldehyde," Bulletin of Materials Science, vol. 29, no. 3, pp. 233-238, 2006.

[46] J. E. Santos, E. R. Dockal, and E. T. G. Cavalheiro, "Thermal behavior of Schiff bases from chitosan," Journal of Thermal Analysis and Calorimetry, vol. 79, no. 2, pp. 243-248, 2005.

[47] T. K. Naiya, A. K. Bhattacharya, and S. K. Das, "Adsorptive removal of Cd(II) ions from aqueous solutions by rice husk ash," Environmental Progress and Sustainable Energy, vol. 28, no. 4, pp. 535-546, 2009.
[48] M. Monier, D. M. Ayad, Y. Wei, and A. A. Sarhan, "Preparation and characterization of magnetic chelating resin based on chitosan for adsorption of $\mathrm{Cu}(\mathrm{II}), \mathrm{Co}(\mathrm{II})$, and $\mathrm{Ni}(\mathrm{II})$ ions," Reactive and Functional Polymers, vol. 70, no. 4, pp. 257-266, 2010.

[49] M. Cieślak-Golonka, "Toxic and mutagenic effects of chromium(VI). A review," Polyhedron, vol. 15, no. 21, pp. 3667-3918, 1996.

[50] M. Horsfall and A. I. Spiff, "Equilibrium sorption study of $\mathrm{Al}^{3+}$, $\mathrm{Co}^{2+}$ and $\mathrm{Ag}^{+}$in aqueous solutions by fluted pumpkin (Telfairia occidentalis HOOK f) waste biomass," Acta Chimica Slovenica, vol. 52, no. 2, pp. 174-181, 2005.

[51] Y. G. Abou El-Reash, M. Otto, I. M. Kenawy, and A. M. Ouf, "Adsorption of Cr (VI) and As (V) ions by modified magnetic chitosan chelating resin," International Journal of Biological Macromolecules, vol. 49, pp. 513-522, 2011.

[52] A. Ikem and N. O. Egiebor, "Assessment of trace elements in canned fishes (mackerel, tuna, salmon, sardines and herrings) marketed in Georgia and Alabama (United States of America)," Journal of Food Composition and Analysis, vol. 18, no. 8, pp. 771787, 2005.

[53] Anonymous, Empfehlungen fun die Nahrstoffzufuhr, Deutsche Gesellschaft fur Ernahrung, Bonn, Germany, 1991.

[54] FAO, "compilation of Legal Limits for hazardous substances in fish and fishery products," FAO Fishery Circular 464, pp. 5-100, 1983. 

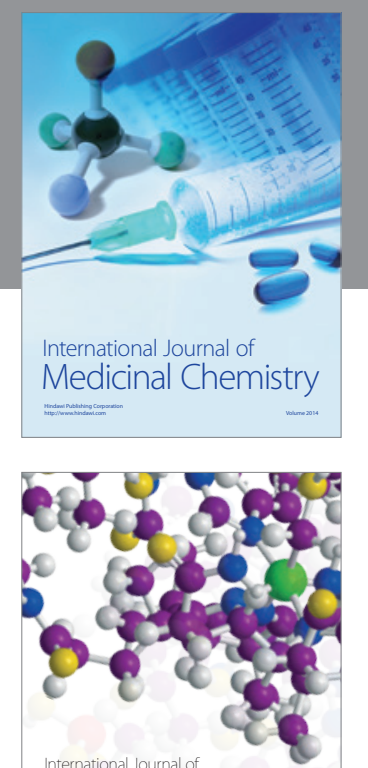

\section{Carbohydrate} Chemistry

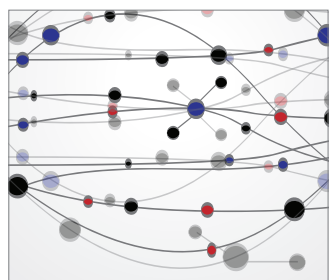

The Scientific World Journal
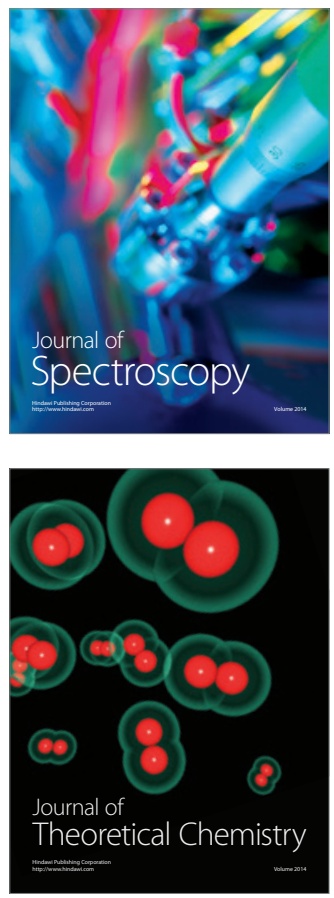
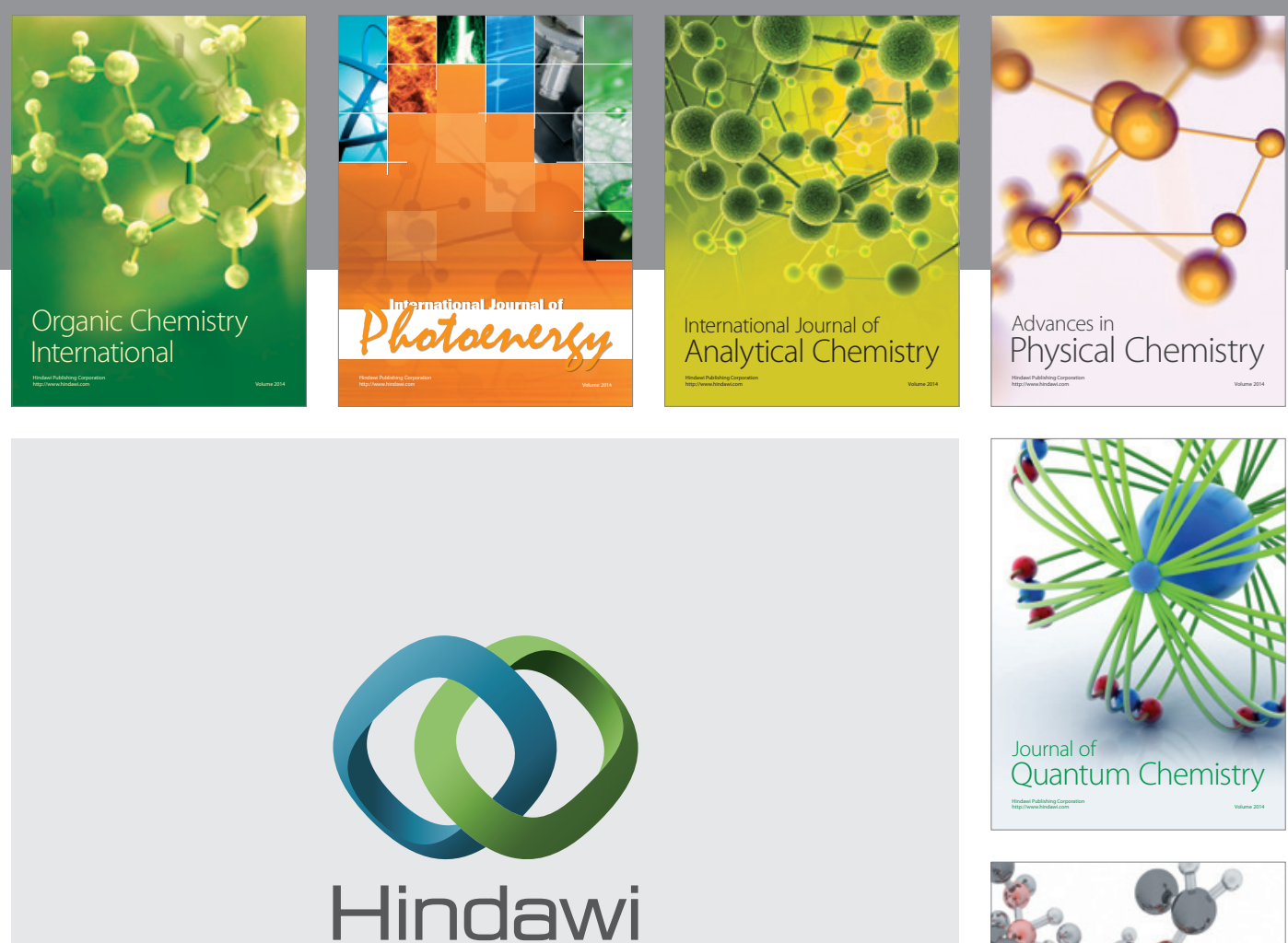

Submit your manuscripts at

http://www.hindawi.com

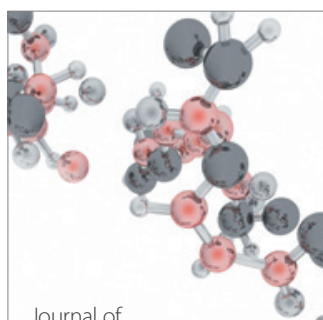

Analytical Methods

in Chemistry

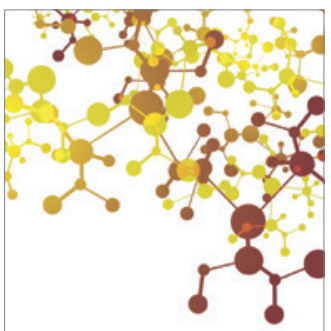

Journal of

Applied Chemistry

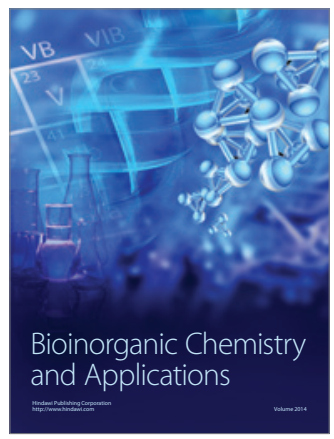

Inorganic Chemistry
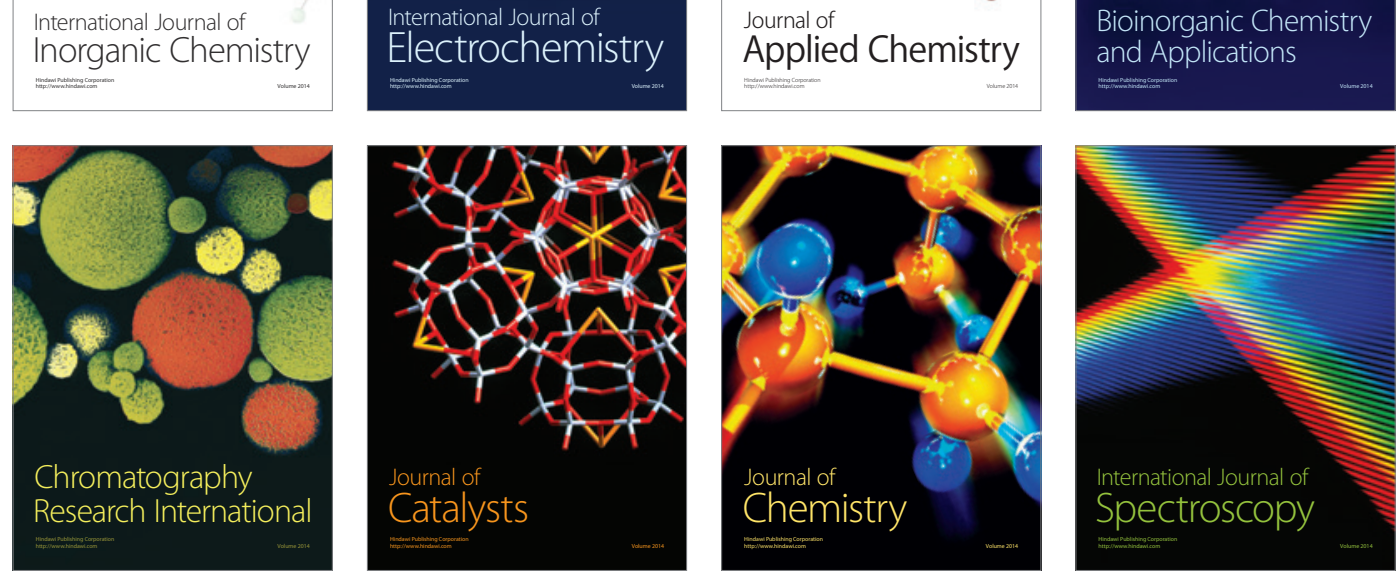